\title{
Hemoglobin D disease
}

INSERM

\section{Source}

INSERM. (1999). Orphanet: an online rare disease and orphan drug data base.

Hemoglobin D disease. ORPHA:90039

Hemoglobin $\mathrm{D}$ disease $(\mathrm{HbD})$ is a hemoglobinopathy characterized by production of abnormal variant hemoglobin known as hemog lobin $\mathrm{D}$, with no or mild clinical manifestations (splenomegaly, very mild anemia). 